\title{
Komunikasi Dakwah Pada Masyarakat Adat Kampung Dukuh Garut
}

\author{
Dede Sihabudin ${ }^{1 *}$ \\ Jurusan Komunikasi dan Penyiaran Islam, Fakultas Dakwah dan Komunikasi, UIN Sunan \\ Gunung Djati, Bandung \\ *Sibabudinhere@gmail.com
}

\begin{abstract}
The Dukub traditional village community is a strong community with the principle of holding ancestral traditions based on Islamic values. The purpose of this study was to describe the experiences, understandings, and meanings of the da'is in Dukuh village and to describe the effectiveness of his da'wah communication. The research method used is the phenomenology method with Harold Lasswell's communication theory which assumes 5 elements of communication. The results of this study indicate that da'i cannot impose heavy material because the majority of the livelihoods of the residents are farmers; each da'i understands that preaching must be carried out by everyone in the village of Hamlet with their respective abilities; the meaning of da'wah according to the preachers in the village of Hamlet is 5T, namely the purpose of inhaling (khaufulläh and rabmatullāh), the task of inhaling (worship), the procedure of hrup (by being obedient to Alläh, apostles and government), inhaled challenges (must be strong against trials), and Tuntung breathes (always expresses bimself to face death by worship). Da'wah in the Dukuh Customary village environment has run quite effectively because the community generally adheres to the $5 T$ principle which has been maintained for generations.
\end{abstract}

Keywords: Da'wah Communication; Indigenous Village; Indigenous Village Da'wah.

\begin{abstract}
ABSTRAK
Masyarakat kampung adat Dukuh merupakan masyarakat yang teguh berprinsip memegang tradisi leluhur berasas nilai-nilai Islam. Tujuan penelitian ini adalah untuk mendeskripsikan pengalaman, pemahaman, dan pemaknaan para da'i yang ada di kampung Dukuh serta menggambarkan keefektifan komunikasi dakwahnya. Metode penelitian yang diguanakn adalah metode fenomenologi dengan teori komunikasi Harold Lasswell yang mengasumsikan 5 unsur komunikasi. Hasil penelitian ini menunjukan bahwa da'i tidak bisa memaksakan materi yang berat karena mayoritas mata pencaharian penduduknya adalah petani; setiap da'i memahami bahwa dakwah wajib dilakukan setiap orang di kampung Dukuh dengan kemampuannya masingmasing; makna dakwah menurut para da'i di kampung Dukuh adalah 5T, yaitu Tujuan hirup(khaufullāh dan rahmatullāh), Tugas hirup (ibadah), Tata cara hrup (dengan taat kepada Allāh, rasul dan pemerintah), Tantangan hirup (harus kuat menghadapi cobaan), dan Tuntung hirup (selalu memperispkan diri untuk menghadapi kematian dengan ibadah). Dakwah di lingkungan kampung Adat Dukuh telah berjalan cukup efektif karena masyarakatnya secara umum memegang teguh prinsip 5T yang telah dijaga secara turun-temurun.
\end{abstract}


Dede Sihabudin

Kata kunci : Komunikasi Dakwah; Kampung Adat; Dakwah Kampung Adat.

\section{PENDAHULUAN}

Manusia dalam memenuhi kebutuhan hidupnya membutuhkan interaksi dengan manusia lainnya. Adanya interaksi antar individu satu dengan individu yang lainnya menjadikan adanya hubungan yang dinamis dalam berbagai aspek yang berkesinambungan terkait peranan masing-masing, seperti dikemukakan Gillin dan Gillin bahwa interaksi merupakan hubungan-hubungan sosial yang dinamis, yang menyangkut hubungan antara orang-perorangan, antara kelompokkelompok manusia, maupun antara orang-perorangan dengan kelompok manusia.

Adat merupakan peraturan yang tidak tertulis dan terjadi secara spontanitas sebagai kontrol atas tingkah laku atau sikap manusia sebagai warga suatu masyarakat sehingga menjadi suatu komplek norma-norma yang oleh individu-individu yang menganutya itu dianggap ada di atas manusia yang hidup bersama dalam kenyataan suatu masyarakat, sehingga dapat dikatakan bahwa masyarakat adat merupakan sekelompok manusia yang telah hidup dan bekerjasama cukup lama sehingga mereka dapat mengatur diri mereka dan mereka dapat memahami norma-norma dan adat istiadat sehingga mereka dapat mengontrol sikap dan tingkah laku sebagai warga suatu masyarakat.

Secara identitas, masyarakat kampung adat Dukuh lebih dikenal luas sebagai masyarakat yang mendiami sebuah kawasan di wilayah Garut Selatan, yang merupakan sebuah kampung adat yang secara kontinyu kehidupan masyarakatnya teguh berprinsip memegang tradisi budaya dan adat istiadat secara turun temurun. Perinsip seperti ini dapat dikatakan sama dengan dakwah dari satu orang kepada satu orang lainnya melalui keluarga secara turun-temurun, dan dakwah tersebut dinamakan model dakwah fardiyah (Suherdiana, 2009: 689).

Salah satu ciri khas masyarakat kampung adat Dukuh adalah hidup dengan penuh kesederhaan sampai saat ini, keunikan lainnya adalah keseragaman struktur dan bentuk arsitektur bangunan pemukimannya. Terdiri beberapa puluh rumah yang tersusun pada kemiringan tanah yang bertingkat. Setiap tingkatan terdapat sederetan rumah yang membujur dari barat ke timur. Di kampung adat Dukuh tidak diperkenankan adanya listrik dan barang-barang elektronik. Sebab barang-barang semacam itu dipercaya selain ada manfaatnya, namun mudharatnya lebih besar lagi. Alat makan yang dianjurkan terbuat dari pepohonan dan alam sekitar. Misalnya terbuat dari bambu, batok kelapa dan kayu. Material tersebut dipercaya lebih memberikan manfaat ekonomis dan kesehatan, karena bahan tersebut tidak mudah hancur atau pecah dan dapat menyerap kotoran. Hal ini menjadi keyakinan masyarakatnya untuk menjunjung harmonisasi dan keselarasan hidup menjadi sebuah pemahaman yang membawa pengaruh pada penerapan budaya hidup sederhana. Hal ini terlihat pada bentuk bangunan di kampung adat Dukuh yang tidak menggunakan dinding dari 
tembok begitupun dengan atap rumah serta jendela kaca. Ini menjadi salah satu aturan yang dilatarbelakangi alasan bahwa hal yang berbau kemewahan akan mengakibatkan suasana hidup bermasyarakat menjadi tidak harmonis.

Adapun dengan segala kesederhanaanya masyarakat kampung adat Dukuh merupakan masyarakat dengan tradisi budaya serta religius yang kuat. Masyarakatnya memiliki pandangan hidup sufisme madzhab Imam Syafi'i. Hal ini tidak terlepas atas peran kepala kampung adat yang sekaligus sebagai Da'i dalam menyebarkan nilai-nilai keislaman di masyarakat kampung adat Dukuh. Terdapat masjid dan madrasah sebagai salah satu bukti adanya aktifitas dakwah. Masjid tersebut sebagai sarana ibadah masyarakatnya yang hingga kini masih digunakan sebagaimana mestinya. Masjid tersebut merupakan sarana utama dalam kegiatan dakwah di masyarakat kampung adat Dukuh meskipun metode yang digunakan lebih kepada khitobah. Aliyudin (2016: 271) mengungkapkan bahwa dalam masyarakat Islam saat ini terdapat banyak prosesi adat yang sarat akan nilai-nilai Islam, dan nilai-nilai tersebut merupakan dakwah dengan cara adat-tradisi.

Terdapat beberapa peraturan yang syarat dengan nilai dan ajaran Islam yang harus ditaati baik oleh masyarakat adat sendiri maupun para tamu yang hendak berkunjung ke kampung adat Dukuh. Seperti, ketika memasuki kampung adat harus berpakaian sopan dan menutup aurat, dalam berperilaku harus sopan santun dan lemah lembut, bertutur kata ramah dan menghormati tamu serta memiliki rasa persaudaraan yang kuat dengan saling gotong royong kepada sesama, antara perempuan dan laki-laki yang bukan muhrimnya harus menjaga hijab (jarak), hal-hal tersebut merupakan keyakinan sesuai dengan tradisi turun temurun maupun ajaran Islam. Kemudian sebagai penghormatan terhadap leluhur masyarakat adat yakni pantangan selonjor kaki ke arah utara, hal tersebut dilakukan karena di arah selatan Kampung Dukuh terdapat makam karomah Syekh Abdul Jalil, seorang ulama besar yang berdakwah menyebarkan Islam pada masyarakat sekaligus pendiri Kampung adat Dukuh.

Adapun pengertian dakwah menurut Taufik Al-Wa i ialah mengumpulkan manusia dalam kebaikan, menunjukkan mereka jalan yang benar dengan cara merealiasikan manhaj Allāh dibumi dalam ucapan dan amalan, menyeru kepada yang makruf an mencegah dari yang munkar, membimbing mereka kepada shirathal mustaqim dan bersabar menghadapi ujian yang menghadang di perjalanan (An-Nabiry, 2008: 17-21), dimana dalam kegiatan dakwah terdapat amalan (perbuatan) juga perkataan yang pada prosesnya dapat berlangsung secara verbal maupun non verbal hal tersebut merupakan bentuk komunikasi dakwah.

Menghubungkan terkait dakwah dan komunikasi bahwa dakwah sebagai proses informasi nilai-inilai keislaman membutuhkan apa yang dinamakan proses pengkomunikasian. Kandungan ajaran Islam yang didakwahkan merupakan sekumpulan pesan-pesan yang dikomunikasikan kepada manusia. Proses dakwah kalau diamati sampai pada tahapan tanggapan mad'u, serta pelaksanaan ajaran 
Dede Sihabudin

keagamaan sebagai hasil dari proses dakwah, maka dapat dilihat bahwa terjadi keselarasan antara proses komunikasi degan proses dakwah. Oleh karenanya, wajar jika banyak orang yang mengatakan bahwa proses dakwah adalah proses komunikasi itu sendiri (Atabik, 2014: 120). Sehingga dakwah pada dasarnya merupakan bagian dari komunikasi. Dakwah juga dapat dipandang sebagai proses penyampaian pesan-pesan tentang kebajikan dari seorang penyeru (Da'i) kepada audiens (mad'u) (Muhtadi, 2012:7), sehingga komunikasi dakwah adalah proses penyampaian informasi atau pesan dari seseorang atau kelompok orang kepada seseorang atau sekelompok orang lainnya yang bersumber dari Al-qur'an dan hadist dengan menggunakan lambang-lambang baik secara verbal maupun non verbal, dimana bertujuan untuk mengubah sikap, pendapat atau perilaku orang lain sesuai dengan ajaran Islam, baik langsung secara lisan maupun tidak langsung melalui media.

Fenomena dakwah yang terdapat dikampung adat Dukuh memiliki keunikan yang tersendiri jika dibandingkan dengan kegiatan dakwah di masyarakat pada umumnya. Salah satu fenomena dakwah di masyarakat kampung adat Dukuh yang menarik yakni sosok Da'i sebagai sesepuh adat atau kepala adat kampung Dukuh yang memiliki pengaruh besar bagi kehidupan beragama masyarakat kampung adat Dukuh yang meliputi tatanan sosial maupun akulturasi Islam budaya lokal, kesantunan, ramah tamah, perilaku sederhana, menjaga lingkungan dengan menghormati alam merupakan beberapa cerminan karifan lokal budaya sunda yang dimiliki oleh masyarakat kampung adat Dukuh syarat akan nilai-nilai islam yang dibawa dalam pesan dakwah. Sehingga dakwah yang dilakukan oleh Da'i di kampung adat Dukuh yang dapat diterima dengan baik oleh masyarakatnya, sesuai dengan tujuan dakwah yakni mampu mengarahkan ke arah perubahan dan kondisi yang lebih baik menurut ajaran agama Islam. Hal ini sesuai dengan aspek komunikasi efektif, dimana komunikator yang baik secara empiris mampu menyampaikan informasi atau pesan (message) kepada komunikan sesuai dengan yang .

Berdasarkan pemaparan diatas, dapat diambil beberapa alasan menarik serta pentingnya mengangkat penelitian ini. Pertama fenomena kegiatan dakwah di masyarakat adat kampung Dukuh adalah peranan sesepuh kampung adat disamping sebagai pemimpin di masyarakat juga berperan sebagai Da'i. Kedua, Adanya perpaduan budaya adat istiadat setempat dengan ajaran Islam yang mampu menciptakan kehidupan masyarakat yang sesuai dengan tuntunan Islam melalui kearifan lokal. Ketiga minimnya penelitian dan literatur yang secara khusus dan spesifik mengkaji kegiatan dakwah yang terjadi di masyarakat adat, khususnya masyarakat kampung adat Dukuh. Ketiga dengan adanya penelitian ini dapat menjadi sumbangsih keilmuan dakwah serta mampu menyajikan deskripsi komunikasi dakwah sehingga dapat memperkaya khazanah keilmuan komunikasi maupun dakwah. Keempat penelitian komunikasi dakwah pada masyarakat adat ini dipandang relevan dengan keilmuan Komunikasi dan 
Penyiaran Islam sehingga menarik untuk dijadikan objek penelitian.

Penelitian ini bertujuan untuk mendeskripsikan pengalaman, pemahaman, dan pemaknaan para da'i yang ada di kampung Dukuh serta menggambarkan keefektifan komunikasi dakwahnya. Metode penelitian yang diguanakn adalah metode fenomenologi dengan teori komunikasi Harold Lasswell yang mengasumsikan 5 unsur komunikasi. Adapun kegunaannya, penelitian ini diharapkan dapat memberikan manfaat baik secara teoritis atau pun praktis. Secara teoritis penelitian ini diharapkan dapat menambah wawasan keilmuan dalam kajian komunikasi dakwah di masyarakat adat. Sedangkan secara praktis penelitian diharapkan dapat menjadi rujukan untuk peneliti-peneliti selanjutnya yang akan mengkaji komunikasi dakwah di lingkungan kampung adat.

Penelitian terdahulu yang berkaitan dan relevan dengan penelitian yang akan dilakukan peneliti. Tujuannya adalah agar peneliti mendapatkan rujukan pendukung, pelengkap, pembanding dan memberi gambaran awal mengenai kajian terkait permasalahan dalam penelitian ini. Berikut ini peneliti temukan beberapa hasil penelitian terdahulu mengenai aktifitas komunikasi maupun dakwah dalam berbagai potret kajian penelitian yang berbeda-beda, diantaranya adalah Nasvian (2013: 1884) yang mengungkapkan bahwa model komunikasi kyai dengan santri memiliki signifikansi yang sangat berbeda. Kemudian Kahinah (2014:2) mengungkapkan bahwa seorang da'i dalam melakukan komunikasi dakwah dalam Masyarakat Multikultural harus mempunyai kemampuan mengaitkan antara tsaqofah (kebudayaan) Islam dengan realita mad'u. Selanjutnya Nurdin (2016: 98) menunjukan bahwa pola tabligh di kampung Adat Dukuh kabupaten Garut menggunakan taradisi yang turun temurun. Selain itu Muharom (2014: 2) melakukan kajian di kampung Naga dan mengungkapkan bahwa suri tauladan baik tokoh agama dalam berdakwah sangat penting seperti memberikan wejangan kepada masyarakat untuk selalu bersikap sopan, baik terhadap sesama manusia, tumbuhan dan pencipta-Nya.

Berdasarkan penelitian-penelitian terdahulu yang relevan dengan penelitian ini, dapat diketahui bahwa penelitian ini membahas tentang komunikasi dakwah yang terdiri dari 5 unsur komunikasi yaitu, da'i, mad'u, uslub, maudu', dan wasilah. Dakwah senantiasa dilakukan dengan mempertimbangkan aspek budaya setempat, terutama untuk mempermudah jalan dakwah yang ditempuhnya (Muhtadi, 2012: 53), disamping itu dalam prespektif komunikasi, aktifitas dakwah dengan mengedepankan kearifan lokal seperti yang dilakukan Rasululllah beserta para sahabatnya merupakan salah satu strategi meningkatkan kekuatan persuasi agar dakwah dapat memberikan efek yang lebih besar (Muhtadi, 2012: 54).

\section{HASIL DAN PEMBAHASAN}

Pengalaman, Pemahaman, dan Pemaknaan Da'i terhadap Dakwah di 
Dede Sihabudin

\section{Kampung Adat Dukuh}

Komunikasi adalah peristiwa penyampaian ide manusia. Oleh karena itu dapat dikatakan bahwa komunikasi merupakan suatu proses penyampaian pesan yang dapat berupa pesan informasi, ide, emosi, keterampilan melalui simbol atau lambang yang dapat menimbulkan efek tertentu, baik tingkah laku yang dilakukan oleh media-media tertentu. Sebagaimana yang telah diuangkapkan pada bab sebelumnya bahwa salah satu indikasi fenomenologi adalah pemahaman. Menurut Rahman (2016: 375) peristiwa komunikasi yang dikaitkan dengan proses dakwah untuk dapat merubah seseorang bahkan kelompok disebut dengan komunikasi Dakwah. Sejalan dengan hal itu, maka berikut ini adalah pembahasan pemahaman da'i tentang dakwah berdasarkan hasil wawancara dengan para Da'i:

Aya sababaraha kendala dinu pelaksanaan salami ieu abdi nyampaikeun ceramah atanapi pangaosan. Hiji Aya rasa "kasiksa" nalika materi nu dibahas eta-eta keneh, mung kumaha deui urang kudu ngarti jeung paham ku kondisi jamaah urang; dua Keterbatasan mustami dalam hal pengetahuan sabingga elmu nu disampaikan kurang aya perkembangan (Hasil wawancara dengan ustadz. Hamzab Nasrullah pada hari Minggu, 6 Mei 2018, pukul 11.00 WIB di Bale Adat, beliau adalah tokoh agama sekaligus penceramah yang berasal dari luar kampung Dukuh dan berusia 41 tahun).

(Ada beberapa kendala pada pelaksanaannya selama saya menyampaikan ceramah mauapun pengajian: 1. Ada perasaan "tersiksa" ketika materi yang dibahas itu-itu saja, tapi mau gimana lagi kita harus mengerti dan faham kondisi jamaah kita, 2. Keterbatasan mustami dalam pengetahuan, sehingga ilmu yang disampaikan tidak banyak perkembangan).

Tentu dalam berdakwah akan selalu ada tantangan, namun yang dialami oleh Da'i-Da'i di lingkungan kampung Dukuh tidak terlalu menantang karena masyarakat kampung Dukuh lebih memudah menerima apa yang disampaikan oleh Da'i. Sebagai mana yang diungkapkan oleh Enjang dan Aliyudin bahwa seseorang yang baik secara langsung maupun tidak langsung, melalui lisan atau tulisan serta perbuatan-perbuatan untuk mengamalkan dan menyebarluaskan ajaran Islam, melakukan upaya kearah kondisi yang lebih baik sesuai dengan ajaran Islam.

Sifat-sifat Da'i, ari Da’i kudu miboga opat sifat pikeun ngalakasnakeun dakwah. Hiji sing ikhlas sareng tawakal, dua sabar sareng dawam, tilu Kudu sesuai sareng tuntutan jaman nu henteu nentang kana syara, opat Ari Da'i mah teu kenging ngarasula. Ari ningali ikhlasna Da'i, aya sababaraha tingkatan darajat ikhlas ka sasama makbluk, diantarana biji Muktasibin: sambil kasab, masib dibarengan jeung ku pangabutuh birup, jeung nu kadua Mutajaridin : ieu mab tingkatan para wali Allāh (Hasil wawancara dengan ustadz Hamzah Nasrullah pada hari Minggu, 6 Mei 2018, pukul 11.56 WIB). 
Komunikasi Dakwah Pada Masyarakat Adat Kampung Dukuh Garut

(Seorang Da'i harus memiliki 4 sifat ketika melaksanakan dakwah, 1. Harus ikhlas dan tawakal, 2. Sabar dan istiqomah, 3. Mampu menyesuaikan dengan tuntutan jaman dengan tidak menentang aturan syara, 4. Jangan banyak mengeluh. Jika melihat keikhlasan seorang Da'i, ada beberapa tingkatan ikhlas ke sesaman makhluk, 1. Muktasibin: sambil kasab. Dibarengi dengan pemenuhan kebutuhan hidupnya, 2. Mutajaridin: merupakan tingkatan para wali Allāh).

Berdasarkan pernyataan tersebut dapat dipahami bahwa seorang Da'i harus memiliki sifat-sifat yang baik sebagai bahan pertimbangan mad'u terhadap tingkah laku Da'i yang tentu akan dicontoh oleh mad'unya. Hal ini sebagaimana yang diungkapkan Mubasyaroh (2017:311) bahwa strategi dakwah persuasif dalam mengubah perilaku masyarakat sangat perlu unutk dirumuskan dengan matang. Berdasarkan keterangan tersebut maka dalam berdakwah terdapat media yang perlu diperhatikan, dan dalam bahasa Arab media disebut juga dengan wasīlah. Secara bahasa kata wasilah berasal dari bahasa arab yang berarti segala hal yang dapat menghantarkan tercapainya kepada sesuatu yang dimaksud (AlBayanuni, 2001: 48). Adapun secara istilah adalah segala sesuatu yang dapat mendekatkan kepada sesuatu lainnya (Al-Misry, 2005: 213).

Syarat diterimanya ibadah adalah rasa ikhlas. Ustadz Nasrullah memetakan ikhlas menjadi poin pertama sebagai pemahaman Da’i dalam berdakwah. Sebagaimana firman Allāh dalam Al-Qur'an sebagai berikut:

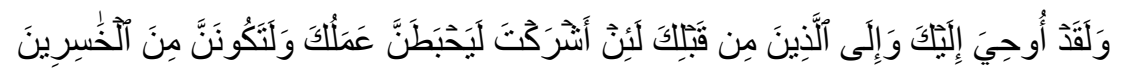

Dan sesungguhnya telah diwahyukan kepadamu dan kepada (nabi-nabi) yang sebelum kamu. "jika kamu mempersekutukan (tuhan), niscaya akan hapuslah amalmu dan tentulah kamu termasuk orang-orang yang merugi. (QS. Az-Zumar: 65).

Dengan demikian, media dakwah atau washilah Dakwah adalah instrumen sebagai saluran pesan yang menghubungkan antara da'i dan mad'u. Adapun washilah merupakan alat objektif yang menjadi saluran yang dapat menghubungkan ide dengan umat, sebagai sebuah elemen yang vital dan merupakan urat nadi dalam totalitas dakwah yang keberadaanya sangat penting dalam menentukan perjalanan dakwah itu sendiri .

Dengan ikhlas, seseorang tidak akan pernah tersesat dari jalan Allah, juga akan terhindar dari riya atau sombong karena sombong dan riya adalah sifat Iblis. Mama uluk menambahkan bahwa seseorang yang hatinya ikhlas bagaikan orang yang sedang membersihkan kerikil-kerikil dan batu-batu kecil di sekitar beras. Apabila beras tersebut telah bersih maka beras yang dimasak akan menjadi nikmat untuk dimakan. Apabila beras tersebut masih kotor dari krikil-kerikil maka ketika nasi dikunyah akan tergigit kerikil kecil. Demikianlah keikhlasan 
Dede Sihabudin

yang akan membuat hidup menjadi nikmat, tidak membuat lelah dan segala pengorbanan yang dilakukan pun tidak akan terasa berat.

Poin pertama yang disampaikan ustadz Hamzah Nasrullah adalah ikhlas dan tawakal. Tawakal atau tawakkul berasal dari bahasa Arab dengan kata wakala yang artinya adalah menyerah kepada Allah (Ad-Dumaji, 2006: 22). Dalam agama Islam, tawakkal berarti berserah diri sepenuhnya kepada Allah dalam menghadapi atau menunggu hasil dari suatu pekerjaan, atau menanti akibat dari suatu keadaan. Makna terminologis dari tawakal adalah suatu sikap mental seseorang yang merupakan hasil dari keyakinannya yang bulat kepada Allah.

Dengan demikian, tawakal kepada Allah bukan berarti penyerahan diri secara mutlak kepada Allah, melainkan penyerahan diri yang harus didahului dengan ikhtiar secara maksimal. Abu Mu'thy Balkhy berkata berkata kepada Hatim al-'Ashom : "Betulkah engkau berjalan tanpa bekal di hutan ini sematamata bertawakal?" Jawabnya : "tidak, aku berpergian jauh pasti berbekal", "lalu apa bekalnya ?" jawabnya: “empat perkara bekalku, yaitu 1) Aku yakin bahwa dunia dan seisinya adalah milik Allah swt., 2) semua makhluk adalah hamba-Nya, 3) segala usaha/bekerja adalah semata hanya factor penyebab saja, sedangkan rizki ada di tangan tuhan, 4) dan aku yakin bahwa ketentuannya pasti berlaku untuk semua makhluk.

Kemudian Mama Uluk menembahkan:

Kumaha jalan nu bener teh? mung iwal ti ahlusunnah wal jamaah. Ngalaksanakeun sakumaha parentah Alläh jeung rosulna, jeung ulah pati-pati wani ngalakonan bal nu matak pibendueun Allāh jeung rosulna Dakwah teh kudu sing jelas, sing eces, aya patokan jeung tujuanna, lain ngan ukur bisa nyalabkeun tapi leuwih ti eta kudu bisa mere katut solusina. Ari kampung adat Dukuh teh kampung islami, sabab adat teh nyaeta agama anu terkandung sesuai pancasila jeumg UUD 45. Hartina kumaha wae tata carana, kudu saluyu jeung adat islami mun di simbolan mah ku iket, iketkeun diri maneh kanu jalan anu bener (hasil wawancara dengan Mama Uluk Lukman pada hari Sabtu, 5 Mei 2018, pukul 16.54 WIB).

(Bagiamana jalan yang benar itu ? tiada lain adalah jalan ahlusunnah wal jamaah, yakni melaksanakan segala yang Allāh dan rasul perintahkan, dan jangan sekali-kali berani untuk berbuat sesuatu yang akan mendatangkan murka atau azab Allāh. Dakwah harus memiliki tujuan yang terarah, memiliki patokan yang jelas, tidak hanya berani menyalahkan tetapi yang paling penting harus mampu memberikan solusi efektif. Kampung adat Dukuh merupakan kampung Islami, sebab adat yang dimaksud disini bermakna agama, sesuai yang terkandung dalam butir-butir pancasila dan UUD 1945. Artinya bagaimanapun caranya, harus sesuai dengan adat islami yang disimbolkan lewat iket (alat penutup kepala khas sunda) yang artinya mengingatkan diri kepada jalan kebenaran). 
Kemudian Mama Uluk menambahkan bahwa dakwah itu pada hakikatnya adalah mengajak. Namun mengajak dalam tatanan norma yang berlaku agar disukai dan mudah diterima oleh mad'u. Berikut ini pernyataan Mama Uluk tersebut:

Saleresna mah kang setiap orang ge pasti punya pemaknaan sendiri tentang dakwah mah, tp upami pendapat pribados mah, ari dakwah teh nyaeta ngajak. Ngadugikeun sajelas-jelasna sesuai aturan syara. Teu kenging dileuwihan komo deui dikirangan, henteu mengenal tempat jeung waktu dimana wae iraha wae dakwah mah bisa dilakonan (Hasil wawancara dengan ustadz. Hamzah Nasrullah pada hari Minggu, 6 Mei 2018 pukul 12.55 WIB di Bale Adat, beliau adalah tokoh agama sekaligus penceramah yang berasal dari luar kampung Dukuh dan berusia 41 tabun).

(Dakwah adalah mengajak. Menyampaikan sejelas-jelasnya sesuai aturan syara (agama). Jangan ditambah-tambahkan apalagi dikurangi, tidak mengenal tempat dan waktu dimanapun, kapanpun, dakwah bisa dilakukan).

Maka dengan pernyataan Mama Uluk terebut, materi yang disampaikan oleh da'I tiak akan dipahami oleh mad'unya apabila seorang da'I tidak menggunakan metode penyampaian yang apaik. Pernyataan ustadz Hamzah tersebut sejalan dengan definisi terminologis dakwah Arifin yang mengungjapkan bahwa dakwah adalah kegiatan ajakan kebaikan baik dalam bentuk lisan, tulisan, maupun tingkah laku yang secara sadar dan berencana untuk mempengaruhi oranglain, baik secara individu maupun kelompok, agar timbul kesadaran serta pengalaman ajaran agama yang disampaikan tanpa adanya unsur pemaksaan.

Kemudian berikut ini pernyataan ketua majlis taklim di kampung adat Dukuh tentang dakwah:

Ari abdi mah tara dakwah, da ari dakwah mah pan ceramah. nya pami ngaos ge ngaos biasa sareng ibu-ibu nu sanesna kitu, ngaderes sasarengan.. Dimana misalkeun pami nuju ngobrolkeun perkawis agami ge tara sapertos jiga guru sareng murid, ah sasarengan weh sapertos rerencangan deui bari teu serius teuing kitu (hasil wawancara dengan ibu Eva pada hari Rabu, 30 Mei 2018 pukul 13.00 WIB, beliau adalah ketua Majelis Ta'lim Ibu-Ibu pengajian di Kampung Dukuh dan berusia 34 tahun).

(Kalau saya tidak berdakwah, kalau dakwah kan ceramah. Kalau untuk pengajian rutinan dengan ibu-ibu biasa bareng-bareng. Kalaupun misalkan ketika berdiskusi masalah atau persoalan keagamaan tidak seperti antara guru dan murid, semuanya bareng bersama-sama seperti teman biasa dan juga tidak terlalu serius).

Berdasarkan keterangan tersebut, maka telah jelas dapat diketahui bahwa ustadz Hamzah sangat memperhatikan strategi menyampaikan pesan dakwahnya kepada jamaah. Karena ceramah yang dilakukan ustadz Hamzah merupakan 
Dede Sihabudin

bagian dari peristiwa komunikasi. Proses komunikasi yang dimaksud adalah interaksi antara individu yang satu dengan yang lainya terjadi komunikasi dalam rangka penyampaian informasi. Pernyataan ini sejalan dengan Oteng Sutisna bahwa komunikasi ialah proses menyalurkan informasi, ide, penjelasan, perasaan, pertanyaan dari orang ke orang lain atau dari kelompok ke kelompok. Ia adalah proses interaksi antara orang-orang atau kelompok-kelompok yang ditujukan untuk mempengaruhi sikap dan perilaku orang-orang dan kelompok-kelompok di dalam suatu organisasi .

Kemudian berdasarkan hasil wawancara tersebut, terdapat pemaknaan dakawh di lingkungan kampung Dukuh yang sangat menarik namun di kampung tersebut telah menjadi sebuah keyakinan pribadi yang universal. Berikut ini pemaknaan dakwah secara umum yang disampaikan oleh Mama Uluk:

Mun urang rek terjun kana dakwah ngajak eling kanu lian, sing inget ku rumus 5T. Naon wae eta the, hiji Tujuan Hirup, Kudu boga elmu loba pangabisa jeung deukeut kanu boga elmu, Loba uget migawe amal-amal kahadean, Sing Ikblas, Kudu boga rada khaof (sieun) mun urang nincak kanu salah, Kudu gede harepan boga sifat roja. Harepan meunang rahmat ti Gusti. Dua Tugas Hirup Jalma, Dalilna jelas tos aya di quran surat adzariyat aya 56 "teu pati-pati kuring nyiptakeun jin jeung manusa saur Allāh iwal keur aribadah kea kami. Sing inget keur ibadah birup the Kudu daek solat, sing pageuh sangkan kadi tihang anu pageuh kuat (Hasil wawancara dengan bapak Edi atau Mang Koboy pada hari Minggu, 8 Juni 2018 pukul 13.55 WIB di Bale Adat, beliau adalah salah satu tokoh masyarakat sekaligus Da'i di kampung Dukuh yang berusia 51 tahun).

(Jika kita akan terjun kedalam dunia dakwah sebagai ajakan, ingatlah rumus 5T. Apa sajakah itu : 1, Tujuan Hidup yaitu Harus memiliki ilmu yang mumpuni dan dekat dengan para pemilik ilmu, Banyak ikhtiar untuk melakukan amal kebaikan, Berusaha ikhlas, Selalu memiliki sifat khaof, rasa takut untuk berbuat maksiat atau salah, Selalu memiliki harapan untuk mendapat rahmat dari Allāh). 2. Tugas Hidup Manusia, Dalilnya secara jelas ada dalam al-Qur'an adz-dariyat : 56 yang artinya "Dan tidaklah aku menciptakan jin dan manusia melainkan agar mereka beribadah (menyembah) kepada-Ku”.

Dengan demikian Mama Uluk menyampaikan dan memberikan peringatan kepada masyarakatnya dengan pemahaman ini bahwa tujuan hidup dan diciptakannya manusia ke muka bumi adalah untuk beribadah kepada Allah swt. Dari pernyataan tersebut dapat dipahami bahwa tujuan hidup didunia ini adalah takut kepada Allāh dan mengharap rahmat Allāh. Takut dalam terminologi islam adalah khouf. $T$ yang pertama adalah Tujuan Hidup, diawali dengan khaufullah. Secara etimologi, kata khauf berasal dari bahasa Arab yang terdiri atas tiga huruf, yaitu khaf, waw dan fa yang mana mengandung makna "ketakutan, kepanikan, terkejut, bingung". 
Sedangkan definisi khauf menurut terminology adalah:

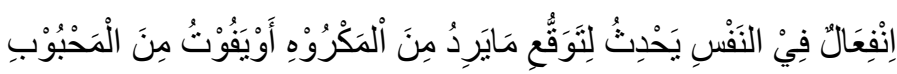

Kondisi (bisikan) kejiwaan yang timbul sebagai akibat dari dugaan akan munculnya sesuatu yang dibenci atau hilangnya sesuatu yang disenangi.

Para pakar tasawuf juga berkomentar tentang pengertian khauf, berikut uraiannya. Al-Ashfahani menyatakan bahwa kha'uf adalah:

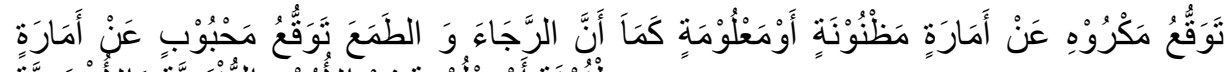

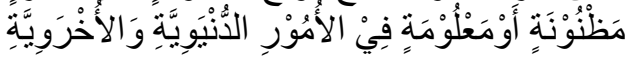

Perkiraan akan terjadinya sesuatu yang dibenci karena bertanda yang diduga atau yang diyakini, sebagaimana harapan dan hasrat tinggi itu adalah perkiraan akan terjadinya sesuatu yang disenangi karena pertanda yang diduga atau diyakini, baik dalam urusan duniawi maupun ukhrawi (Shihab , 2007: 473).

Imam al-Ghazali berkata bahwa hakikat dari khauf adalah kepedihan dan terbakarnya hati karena memperkirakan akan tertimpa sesuatu yang tidak menyenangkan di masa yang akan dating. Rasa takut kepada Allah juga terkadang timbul dari dalam diri seseorang karena perbuatan dosa yang telah dilakukannya, juga dapat timbul dari sifat-sifat Allah yang diketahui oleh seseorang tersebut. Inilah tingkatan khauf yang paling sempurna. Sebab barang siapa yang mengetahui Allāh, maka dia akan takut kepadaNya. Oleh karena itu, Allah berfirman:

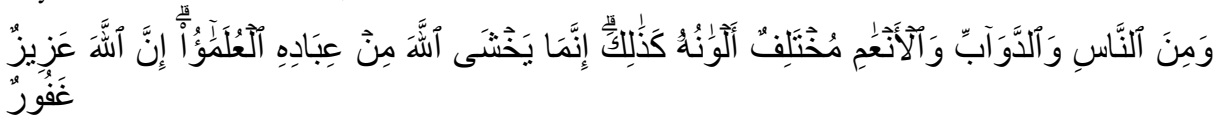

Dan demikian (pula) di antara manusia, binatang-binatang melata dan binatang-binatang ternak ada yang bermacam-macam warnanya (dan jenisnya). Sesungguhnya yang takut kepada Allāh di antara hamba-hambaNya, hanyalah ulama. Sesungguhnya Allāh Maha Perkasa lagi Maha Pengampun. (QS. Fathir: 28).

T yang kedua adalah Tugas Hidup didunia adalah Ibadah. Berdasarkan firman Allāh sebagai berikut:

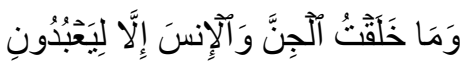

Dan aku tidak menciptakan jin dan manusia melainkan supaya mereka mengabdi kepada-Ku (QS. Adz Dzariyat: 56).

Berdasarkan ayat Al-Quran tersebut, dapat diketahui bahwa tujuan diciptakannya manusia adalah untuk beribadah kepada Allah swt. ayat ini pula mengisyaratkan tentang pentingnya tauhidullah karena tahuid adalah bentuk ibadah yang paling agung dengan mengesakan Allah swt. maka dengan demikian 
Dede Sihabudin

dapat dikatakan bahwa pernyataan Mama Uluk tentang Tujuan Hidup sebagai prinsip dasar masyarakat kampong dukuh dapat dikatakan sejalan dengan AlQuran Surat Ad-Dzariyat ayat 56.

Selain itu, ayat ini juga menyisyaraktakan tentang pentingnya beramal sholih, setelah tujuan pertama manusia diciptakan adalah agar berilmu, Maka buah dari ilmu adalah beramal. Tidaklah ilmu itu dapat dicari dan dipelajari kecuali untuk diamalkan. Sebagaimana pohon, tidaklah pohon itu ditanam kecuali untuk diambil dan dinikmati buahnya, maka dari itu, ilmu adalah buah dari amal dan penting bagi seseorang untuk mengamalkan ilmu yang telah dimilikinya.

Berikut ini lanjutan hasil wawancara dengan

Nah nu katiluna nyaeta Tata Cara Hirup, Gampilna mah turut ka Allāh, ka rasul. Ka pamarentah nu eta pamarentah teh nurut oge kana aturan Allāh jeung Rasulna. Nu kaopat na Tantangan Hirup, Geus pasti kasebutna ari jalma hirup mah bakal loba gogodana, sok komo deui mun urang aya dina jalan hade. Matak kudu kuat mental lahir batin mun urang geus yakin pijalaneun nu bener mah. T nu kalmia nyaeta Tuntung Hirup/Maot, Aya paribasa gajab mati ningalkeun gading, maung paeh ningalkeun belang. Kitu deui ka manusa, naon tatapakan salama hirup teh bakal jadi balitungan pangeran (Hasil wawancara dengan bapak Edi atau Mang Koboy pada hari Minggu, 8 Juni 2018 pukul 14.13 WIB di Bale Adat).

(3. Tata Cara Hidup, Secara mudahnya adalah mentaati Allāh, Rasulnya, dan kepada pemerintah yang juga mengikuti dan mentaati Allāh dan rasulnya). (4. Tantangan Hidup, Sudah menjadi keharusan jika hidup manusia selalu penuh dengan godaan. Apalagi jika kita berada dalam jalan yang benar. Oleh karena itu harus kuat mental lahir batin jika kita meyakini jalan yang dilalui berada sesuai arah kebenaran. (5. Akhir Hidup, Kematian. Sesuai dengan pribahasa "gajah mati meninggalkan gading, harimau mati meninggalkan belang”, begitu pun dengan manusia, segala perbuatannya akan dimintai pertanggungjawaban oleh Allāh SW'T).

T yang ketiga adalah Tata cara hidup di dunia. Da'i di kampung Dukuh melandaskan pemikirannya terhadap Al-Quran surat An-Nisa ayat 59 sebagai mana berikut:

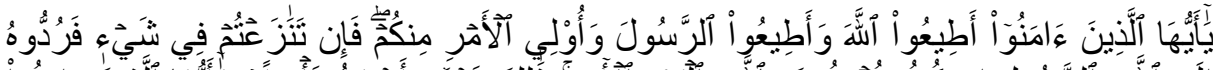

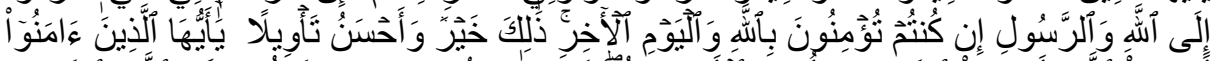

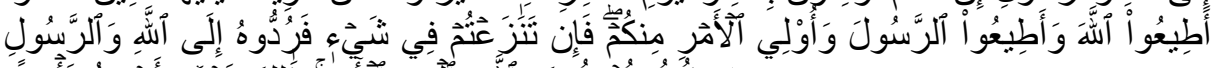

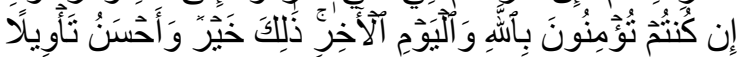

Hai orang-orang yang beriman, taatilah Allāh dan taatilah Rasul (Nya), dan ulil amri di antara kamu. Kemudian jika kamu berlainan pendapat tentang sesuatu, maka kembalikanlah ia kepada Allāh (Al Quran) dan Rasul 
Komunikasi Dakwah Pada Masyarakat Adat Kampung Dukuh Garut

(sunnahnya), jika kamu benar-benar beriman kepada Allāh dan hari kemudian. Yang demikian itu lebih utama (bagimu) dan lebih baik akibatnya (QS. An-Nisa: 59).

T yang keempat adalah tantangan. Semaikn tinggi bumi dipijak maka akan semakin kencang pula angina yang berhembus. Tentu akan berbeda cobaan hidup yang dialami oleh setiap orang. Namun setidaknya di warga masyarakat kampung Dukuh sudah beredar $T$ yang keempat bahwa setiap orang akan mendapatkan cobaan apa pun dan dari manapun di dunia ini, dan setiap orang di kampung Dukuh akan berpikir bahwa tantangan atau cobaan hidup tersebut akan dapat diselesaikan dengan baik karena Allāh tidak akan pernah ada cobaan diatas kemampuan hambanya. Hal ini sejalan dengan QS. Al-Baqarah ayat 286 sebagai mana berikut:

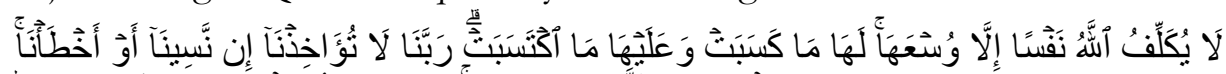

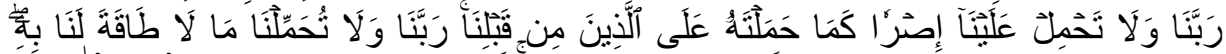

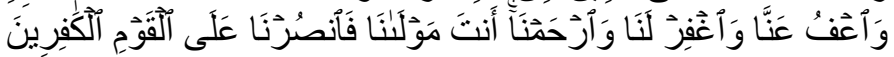

Allāh tidak membebani seseorang melainkan sesuai dengan kesanggupannya. Ia mendapat pahala (dari kebajikan) yang diusahakannya dan ia mendapat siksa (dari kejahatan) yang dikerjakannya. (Mereka berdoa): "Ya Tuhan kami, janganlah Engkau hukum kami jika kami lupa atau kami tersalah. Ya Tuhan kami, janganlah Engkau bebankan kepada kami beban yang berat sebagaimana Engkau bebankan kepada orangorang sebelum kami. Ya Tuhan kami, janganlah Engkau pikulkan kepada kami apa yang tak sanggup kami memikulnya. Beri maaflah kami; ampunilah kami; dan rahmatilah kami. Engkaulah Penolong kami, maka tolonglah kami terhadap kaum yang kafir" (QS. Al-Baqarah: 286).

Banyak orang memahami ayat ini dengan mengatakan, kemampuan yang dimaksud dalam ayat ini adalah batasan minimal kemampuan seseorang. Oleh karena itu, kempuan dapat berubah-ubah tergantung dengan motivasi seseorang tersebut. Ada orang yang tidak mampu untuk melakukan sesuatu, dan ada pula yang mampu melakukannya. Tentu saja pendapat tersebut keliru, karena para sahabat mencontohkan secara nyata bahwa mereka berkomitmen dengan seluruh kapasitas kemampuan mereka.

Di antara para sahabat yang mencoba menafsirkan ayat tersebut adalah adalah Thufail bin Nu'man dengan 13 luka di tubuhnya dan Kharrasy bin As-Simmah dengan 10 luka di tubuhnya. Semua menunjukan bahwa:

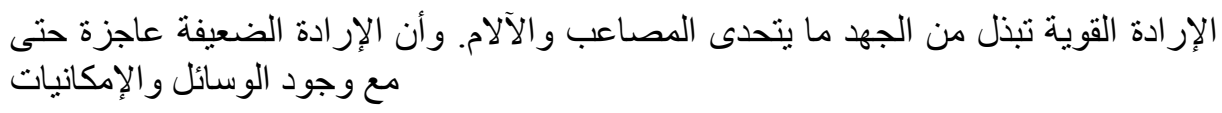

Kemauan yang kuat akan mengerahkan seluruh kesungguhan, walau menghadapi banyak kesulitan penderitaan. Sebaliknya, kemauan yang 
Dede Sihabudin

lemah menjadi tak berdaya meskipun sarana dan waktu tersedia.

Maka berdasarkan penjelasan tersebut, warga masyarakat kampung Dukuh yang apabila akan mendapatkan cobaan apa pun dan dari manapun, akan berpikir bahwa tantangan atau cobaan hidup tersebut akan dapat diselesaikan dengan baik karena Allāh tidak akan pernah memberikan cobaan diatas kemampuan hambanya.

T yang kelima adalah Tungtung Hirup atau mati. Allāh SWT berfirman:

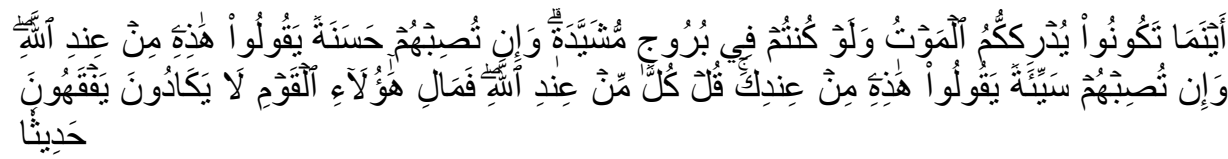

Di mana saja kamu berada, kematian akan mendapatkan kamu, kendatipun kamu di dalam benteng yang tinggi lagi kokoh, dan jika mereka memperoleh kebaikan, mereka mengatakan: "Ini adalah dari sisi Allāh", dan kalau mereka ditimpa sesuatu bencana mereka mengatakan: "Ini (datangnya) dari sisi kamu (Muhammad)". Katakanlah: "Semuanya (datang) dari sisi Allāh". Maka mengapa orang-orang itu (orang munafik) hampir-hampir tidak memahami pembicaraan sedikitpun? (Q.S An-Nisa: 78).

Apabila ayat ini dijaki lebih mendalam dapat diketahui bahwa kematian seseorang itu hanyalah Allah yang tahu waktu dan tempat juga keadaanya, meski pun seseorang tersebut hendak lari dari kematian namun Allah tetap akan bisa mencabut nyawa manusia itu pada saatnya. Maka dari itu seorang manusia yang bertaqwa adalah orang yang mempersiapkan diri untuk menghadapi kematian sehingga ia akan siap kapan pun ketika ajal akan menjemputnya. Hal ini pula sejalan dengan pernyataan Mama Uluk tentang $T$ yang kelima bahwa manusia itu akan merasa sangat rugi apabila ketika hidup di dunia ia hanya memikirkan urusan dunianya saja tanpa menyiapkan bekal yang cukup untuk kehidupan abadi di akheratnya kelak.

Berpedoman dari firman Allāh sebagai mana berikut:

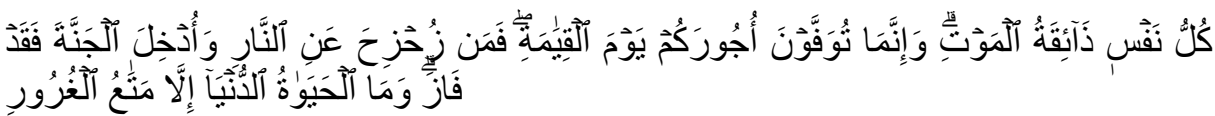

Tiap-tiap yang berjiwa akan merasakan mati. Dan sesungguhnya pada hari kiamat sajalah disempurnakan pahalamu. Barangsiapa dijauhkan dari neraka dan dimasukkan ke dalam surga, maka sungguh ia telah beruntung. Kehidupan dunia itu tidak lain hanyalah kesenangan yang memperdayakan.

(Q.S Ali-Imron:185).

Merujuk kepada ayat tersebut, maka ayat ini dapat memberikan penjelasan kepada pembacanya untuk dapat mempersiapkan diri dalam menghadapi kematian yang tidak bisa ditebak kapanpun kedatangannya. Seorang Sufis berkata 
Komunikasi Dakwah Pada Masyarakat Adat Kampung Dukuh Garut

bahwa dunia itu bagaikan sebuah lautan yang luas dan dalam, dan manusia bagaikan seorang pelaut yang belum mempunyai arah dan tujuan. Apabila manusia tidak istiqomah dalam beriman dan bertaqwa maka ia akan tenggelam di dalam lautan itu. Dengan demikian manusia diharapkan untuk waspada terhadap datangnya kematian di dalam kehidupannya sehari-hari dengan berbekal yang sebaik-baiknya bekal untuk kehidupan akherat kelak.

\section{Keefektifan Dakwah di Kampung Adat Dukuh}

Berdasarkan teori medan dakwah, dapat diketahui bahwa suasana lapangan dakwah dapat ditinjau dari situasi teologis, kultural dan stuktural mad'u (masyarakat) pada saat permulaan pelaksanaan dakwah Islam. Demi tegaknya tata sosial yang adil dalam ridha Allah harus menjadi komitmen setiap muslim karena dakwah diwajibkan meski dilaksanakan dalam situasi sosio-kultural, termasuk bagi masyarakat yang nihil budaya dan nihil sistem. Berikut ini pernyataan-pernyataan masyarakat dari berbagai kalangan tentang keefektifan dakwah yang dilakukan para da'i di lingkungan kampung Dukuh:

Nya ari kegiatan dakwah nu aya di kampung adat Dukuh mah seueur sapertos pangaosan. Mung pami kegiatan masyarakatna mah sami wae sareng kegiatan masyarakat umumna teu tebih. Pangaosan nu rutin dilaksanakeun bususna kangge ibu-ibu didieu saminggu aya 3 kali, dinten minggu, salasa, sareng kemis. Upami bapa-bapa mah sok dinten jumaah. Ustadna ge sok benten-benten nu sok biasa mah sapertos Mama Uluk (Sesepub Kampung adat Dukub), Ustad Nasrulloh. Jamaah pangaosan mah sok resep ka ustad teh nu sok bari heureuy da eta nu sok kaharti mah. Ari pembahasanna mah sok aya fiqih, muamalah, jeung syariah. Ari fiqih mah kadang tentang sholat, muamalah mah kumaha carana birup akur jeung batur, ari syariah mah aturan-aturan agama (hasil wawancara dengan bapak Saepudin pada hari Sabtu, 7 Juni 2018 pukul 10.00 WIB di rumahnya, beliau adalah ketua RT 01 Kampung Dukuh Dalam yang berusia 46 tahun).

(Adapun kegiatan dakwah yang ada di kampung adat Dukuh adalah pengajian. Dan untuk kegiatan masyarakatnya sama seperti kegiatan masyarakat pada umumnya tidak jauh berbeda. Pengajian khusus ibu-ibu dilaksanakan seminggu 3 kali, pada hari minggu, selasa dan kamis. Untuk pengajian bapak-bapak dilaksanakan hari jum'at. Ustad yang biasa mengisi pengajian berbeda-beda orang, hanya biasanya Mama Uluk (Sesepuh kampung adat Dukuh), ustad Nasrulloh. Jamaah menyukai gaya ustad ketika pengajian yang humoris karena mudah dimengerti. Untuk pembahasannya biasanya terkait fiqih, muamalah dan syariah. Untuk fiqih kadang tentang sholat, muamalah terkait bagaimana hubungan perilaku dengan sesama, dan syariah terkait aturan-aturan agama).

Dakwah Islam adalah suatu ikhtiar muslim untuk mewujudkan kehidupan berlandaskan Islam dalam berbagai aspek kehidupan, baik kehidupan pribadi (fardiyah, keluarga (usrah), komunitas (jama'a), dan masyarakat (ummah), 
Dede Sihabudin

sehingga dalam semua segi kehidupan sampai terwujud sebuah khairul ummah (masyarakat terbaik). Khairul umah adalah tata sosial yang sebagian besar anggotanya bertauhid (beriman), senantiasa menegakan yang ma'ruf (tata sosial yang adil) secara berjamaah senantiasa mencegah yang mungkar (tata sosial yang dhalim).

Dakwah merupakan kewajiban bagiumat Islam, selain itu dakwah merupakan ibadah, dakwah itu proses menyampaikan materi atau pesan dakwah yang berupa ajaran-ajaran Islam yang tentu bersumber dari dua pokok sumber utama ajaran Islam yaitu Al-Quran dan As-Sunnah, dari seorang da'i kepada mad'uny dengan baik. sehingga dari proses penyampaian dakwah ini adalah dapat tersampaikanya pesan dakwah dari Da'i kepada mad'unya dengan baik. Namun realitasnya yang ada Da'i lebih cenderung dengan metodenya sendiri tanpa memperhatikan dari berbagai aspek lainya misalnya, dari gaya retorikanya, penyampaian pesanya, humornya, dan aspek psikososiologinya mad'u itu sendiri.

Padahal proses penyampaian dakwah tentu akan lebih baik dan menjadi sangat efektif kalau Da'i mampu dan bisa memahami psikososiologi mad'unya itu sendiri. Kita tau bawha mad,u itu, ada yang cenderung sangat menyukai pada humor dalam setiap dakwahnya. Karna bagaimanapun juga humor dalam dakwah itu sangat dibutuhkan, dan diperlukan oleh mad'u. Atas dasar itulah perlunya seorang da,i dituntut kepandaian dalam berhumor. Tentunya tidak hanya sekedar humor saja, tapi yang mempunya isi pesan humor yang disampaikan dalam dakwahnya.

Ungkapak-uangkapan dakwah tersebut sejalan dengan pendapaat Safei (2002: 223) bahwa dakwah yang berhasil adalah dakwah yang menimbulkan perubahan social kea rah yang lebih baik. Kemudian bapak Hanafi menambahkan "Ari dakwah didieu mah ti kapungkur oge nyaeta sok aya pangaosan kitab. Ari dikampung Dukuh kunaon sok seueur larangan kitu kieu eta teh saleresna lain jelema nu nyieun larangan, mung tempat nu ngalarang" (hasil wawancara dengan bapak Hanafi pada hari, Sabtu 7 Juni 2018 pukul 11.30 WIB di rumahnya, beliau adalah salah satu tokoh masyarakat kampung adat Dukuh yang berusia 70 tahun). (Kegiatan dakwah disini sejak dulu adanya pengajian kitab. Di kampung Dukuh adanya banyak aturan maupun larangan itu bukan manusia yang membuat tetapi tempatlah yang melarang).

Bapak Hanafi lebih cenderung menyampaikan tentang dakwah praktis yang dapat merubah diri seseorang yang krang baik menjadi yang baik, dan yang baik menjadi lebih baik. Yang diungkapkan oleh bapak Hanafi sebagaimana pembahasan tentang akhlak mulia, bahwa yang disebut dengan akhlaq mulia adalah tonggak utama dalam berdakwah di jalan Allah swt. bahkan menjadi syarat utama bagi seorang da'i agar dapat memberikan suritauladan yang baik bagi mad'unya.

Berdakwah mengguanakan akhlaq yang mulia merupakan dakwah yang paling efektif untuk dilakukan, karena dekwah dengan metode ini mengajak 
Komunikasi Dakwah Pada Masyarakat Adat Kampung Dukuh Garut

manusia dengan mencontohkan akhlaqnya kepada manusia yang hendak diajaknya. Malalui ceramah-ceramah yang disampaikan oleh para da'i kepada masyarakat, warga masyarakat kampung Dukuh telah berusaha untuk melaksanakan hasil-hasil ceramah yang disampaikan untuk pribadi yang lebih baik.

Dakwah sebagai kegiatan dalam rangka menegakkan ajaran Islam agar diketahui, dipahami, dihayati dan dilaksanakan oleh seluruh umat, tentu harus memiliki para juru dakwah yang berkualitas. Sungguh sangat banyak orang yang masuk Islam karena terpesona dan terkesan akan akhlaq rosulullah saw. Hal ini sebagaimana yang diungkapkan oleh bapak syarif, berikut ini pernyataan dari bapak Syarif:

Abdi tos linggih didieu kirang langkung 20 taunan. Ari perkawis dakwah mah nyaeta perkawis fiqih. Sapertos kumaha cara sholat nu bener, hade ka batur someah ka semah, teu kenging nyarioskeun batur, pami nyarios kedah nu sae, teu kenging kasar, ulah nyinggung batur komo deui dugi ka nganyerihatekeun batur mah. Abdi mab Sok resep ka ustad nu ngadungikeun ceramah atanapi pangaosan teh bari beureuy loba banyolna kumargi gampil dipahamina. Kangge abdi mah pangaosan teh kawajiban mun henteu dilaksanakeun teh asa dosa. Oge saleresna mah pami masyarakat didieu mah langkung nurut keneh ku bahasa pamali, sabab pamali eta tos aya ti luluburna mun ku urang teu dilaksanakeun bakal wae aya mamala nu bakal kaalaman ku urang (hasil wawancara dengan bapak Syarif pada hari, Minggu 8 Juni 2018 pukul 14.00 WIB di Bale Adat, beliau adalah warga atau masyarakat kampung adat Dukuh yang berusia 45 tahun).

(Saya sudah menetap disini kurang lebih selama 20 tahun. Terkait dakwah adalah masalah fiqih. Seperti bagaimana tata sholat yang benar, baik terhadap sesama dan menghormati tamu, tidak boleh membicarakan oranglain, dan jika berbicara harus dengan perkataan yang baik, tidak kasar, menyinggung apalagi membuat orang lain sakit hati. Saya pribadi menyukai gaya ustad yang ketika memberikan ceramah atau pengajian diselingi dengan bercanda atau guyon, karena hal itu materinya menjadi mudah dipahami. Untuk saya pribadi pengajian adalah kewajiban yang mersa berdosa apabila meninggalkannya. Dan juga sebenarnya masyarakat disini lebih turut kepada bahasa atau istilah pamali. Sebab istilah pamali merupakan aturan leluhur yang apabila tidak dihiraukan akan terjadi sesuatu untuk kita).

Kemudian bapak Syarif menambahkan :

Kumargi urang dieu mah upami teu ngiring pangaosan teh rumaos dosa, janten asa dosa we upami tu ngiringan teh. Teras perkawis materi nu didugikeun ku para ustad didieu mah alhamdulullah kahartos, da abdi pribados mah sok sanaos teu ngiring pangaosan jalaran padamelan tapi aya pun bojo nu ngiringan teras ngawartosan hasil pangaosan teh naon wae. Janten upami teu ngiring pangaosan oge sok aya jang 
Dede Sihabudin

tafakureun diri kenging informasi ti bojo perkawis materi pangaosannana teh (hasil wawancara dengan bapak Syarif pada hari, Minggu 8 Juni 2018 pukul 14.00 WIB di Bale Adat, beliau adalah warga atau masyarakat kampung adat Dukuh yang berusia 45 tahun).

(karena orang sini apabila tidak mengikuti pengajian akan merasa berdosa, jadi seperti berdosa saja saat tidak mengikuti pengajian. Kemudian tentang materi yang disampaikan para ustadz disini alhamdulillah dapat dimengerti, saya pribadi meskipun tidak mengikuti pengajian karena alasan pekerjaan, tapi ada istri yang mengikutinya kemudian memberitakan hasil dari pengajian tersebut. Maka meskipun tidak mengikuti pengajian pun selalu ada bahan untuk mentafakuri diri dari informasi yang disampaikan oleh istri terkait materi pengajian tersebut). Berdasarkan pernyataan ini dapat diketahui bahwa orang kampung Dukuh yang mengikuti pengajian akan memberikan informasi materi yang disampaikan muballigh kepada keluarganya sehingga akan menjadi bahan mengkaji diri dan memperbaiki diri.

Juru dakwah tersebut sejatinya adalah orang yang mengerti hakikat Islam dan mengetahui apa yang sedang berkembang di masyarakat. Adapun kesuksesan dakwah tentu sangat dipengaruhi oleh kualitas dan kepribadian seorang da'i. Dengan kualitas yang dimiliki seorang da'i maka ia akan mendapatkan kepercayaan (kredibilitas) serta citra yang positif di mata para mad'u, baik secara individu maupun masyarakat.

Kemudian kang Koboy menambahkan:

Ari dakwah teh nyaeta Dilalatul Afdhol khoeru Min Dilalatil Aqwal. Nudubkeun ku tingkah laku teh langkung utami tibatan ucapan. Sok ka masjid, bari nu ngomongna bari cicing diuk wae mab moal digugu. Sok geura solat, ari nu nitahna tara solat bakal sia-sia. Sabab ucapan mah sok kadang loba salahna atawa kaceletot leutah. Matak aya istilah Salamatul insan fii hifdril lisaan, salametna manusa kumaha bisa ngajaga atawa nyalametkeun naon ucapanana atanapi omonganana (Hasil wawancara dengan bapak Edi atau Mang Koboy pada hari Minggu, 8 Juni 2018 pukul 12.30 WIB di Bale Adat, beliau adalah salah satu tokoh masyarakat sekaligus Da'i di kampung Dukuh yang berusia 51 tahun).

(Dakwah yaitu Dilalatul Afdhol khoeru min dilalatil aqwal. Menunjukan sesuatu dengan tingkah laku lebih utama dari pada hanya dengan ucapan. Ayo pergi ke masjid, sedangkan orang yang menyuruh atau mengatakan hanya duduk tidakakan berpengaruh apa-apa. Ayo sholat, sedangkan orang yang mengatakannya tidak sholat akan sia-sia. Sebab ucapan terkadang banyak salah atau keseleo lidah. Maka ada istilah salamatul insan fii hifdzil lisaan. Selamatnya diri maunusia adalah tergantung bagaimana ia menjaga lisannya atau perkataannya) di tengah masyarakat, yang mana tugasnya adalah menterjemahkan teori-teori kebaikan dalam amaliah nyata, sehingga 
Komunikasi Dakwah Pada Masyarakat Adat Kampung Dukuh Garut teori tersebut tidak selalu hanya di tulis dalam lembaran kertas. Berikut ini pernyataan Mang Koboy yang sejalan dengan pernyataan tersebut:

Di kampung Dukuh mah teu aya dakwah kudu anu-anu, nu penting mah sing eling urang teh bakal dibisab di poe jaga. Sing inget Jaroh, naon ari jaroh? Ja teh hartina datang, ari roh hartina hirup. Sangkan jaroh teh sing inget yen urang teh datang timana jeung balik bakal kamana. Da ari ngobrolkeun dakwah saur aki mah dakwah teh nyaeta nyaram kanu lepat, upami teu nurut mah kumaha masing-masing weh eta mah.. Kudu ngutamikeun kasih sayang sarta bisa merangan hawa nafsu (hasil wawancara dengan bapak Habib Bakar pada hari Sabtu, 14 Juni 2018 pukul 16.30 WIB di rumahnya, beliau adalah salah satu tokoh Masyarakat adat Kampung Dukuh yang berusia 72 tahun).

(Dikampung Dukuh tidak ada dakwah harus seperti apa, yang penting selalu ingat kalau kita akan dihisab dihari akhir nanti. Harus ingat jaroh, apa itu jaroh? Ja artinya datang, sedangkan roh artinya hidup. Jadi jaroh pada hakikatnya adalah kita harus ingat asal darimana dan kemana kita akan kembali. Kalau berbicara terkait dakwah, menurut aki (kakek) dakwah adalah mencegah kepada hal yang salah, kalaupun tidak menurut itu terserah masing-masing. Mengutamakan kasih sayang serta bisa memerangi hawa nafsu.

Dalam pernyataan tersebut telah nampak bahwa di daialm benak masyarakat telah tertanam motibasi untuk selamat pada hari hisab setelah hari kiamat nanti. Peristiwa hisab merupakan waktu dimana Allah menampakan kepada manusia amalan mereka di dunia dan menetapkannya, atau Allah mengingatkan dan memberitahukan kepada manusia tentang amalan kebaikan dan keburukan yang telah mereka lakukan di dunia.

Sebagaimana uangkapan dari Ibnu Taimiyah yang mengungkapkan bahwa Allah akan menghisab seluruh makhluk-Nya lalu menetapkan dosa-dosa yang dilakukannya. Kemudian syeikh Ali mengomentari pandangan ini dengan menyatakan bahwa inilah proses hisab. Juga syeikh Utsamin yang menyatakan bahwa muhasabah adalah proses manusia melihat amalan mereka pada hari kiamat ('Utsaimin, 1994 :152).

Kemudian dilanjutkan dengan pernyataan dari bapak Nanang yang berpendapat tentang dakwah yang didahulukan oleh para Da'i di lingkungan kampung Dukuh, sebagai berikut:

Ari saur bapa mah dakwah teh ceramah-ceramah anu sok didugikeun ku ustad-ustad boh nuju pangaosan rutinan atanapi di panggung-panggung. Rupi-rupi ari pembahasanna. Kadangkawis masalah fiqih, masalah sholat, masalah zakat sareng seueur deui. Sok langkung kahartos mun ustad nu ngadugikeunana teh bari heureuy benteu serius teuing (hasil wawancara dengan Bapak Nanang pada hari Sabtu, 14 Juni 2018 pukul 14.00 WIB di rumahnya, beilau adalah salahsatu Warga masyarakat Adat Kampung Dukuh yang berusia 50 tahun). 
(Menurut bapak dakwah yaitu ceramah-ceramah yang disampaikan oleh ustad-ustad baik ketika pengajian rutin atau dipanggung-panggung. Bermacam-macam materi pembahasan yang disampaikan. Ada tentang fiqih, masalah sholat, masalah zakat, dan yang lainnya. Lebih mudah dimengerti ketika ustad menyampaikan ceramahnya disertai bercanda tidak terlalu serius)

Dakwah teh nyaeta cara pikeun ngelingan batur nu kasasar, lain kudu dicarekan komo deui dibenduan mah. Matak naon kedah aya pangaosan oge, eta teh salah sabiji cara ngalap elmu sangkan birup ulah kasasar. Da ari birup mah lain ngan saukur dahar jeung barang gawe, kudu loba ibadah keur bekel jaga urang balike ka alam kubur (hasil wawancara dengan Bapak Syafe'i pada hari Minggu, 15 Juni 2018 pukul 16.40 WIB di Bale Adat, beliau adalah salahsatu tokoh Masyarakat adat Kampung Dukuh yang berusia 72 tahun).

(Dakwah merupakan salah satu cara untuk mengingatkan oranglain agar tidak salah arah, dan bukan berarti harus dimarahi. Oleh sebab itu kenapa harus ada pengajian, itu merupakan salah satu cara untuk mendapatkan ilmu sehingga hidup tidak salah arah. Hidup bukan hanya sebatas makan dan bekerja,harus lebih memperbanyak ibadah untuk bekal nanti setelah meninggal dan masuk ke alam kubur).

Mengingat kematian merupakan ibadah tersendiri, karena dengan mengingat kematian akan memberikan renungan dan muhasabah diri untuk dapat menginggat dan mempersiapkan kematian sendiri. Dengan mengingatnya pun seseorang telah mendapatkan ganjaran karena inilah yang diperintahkan oleh nabi Muhammad saw. Bahwa mengingat kematian dapat membuat seseorang khusu' di dalam sholatnya sebagaimana sabda nabi sebagi berikut:

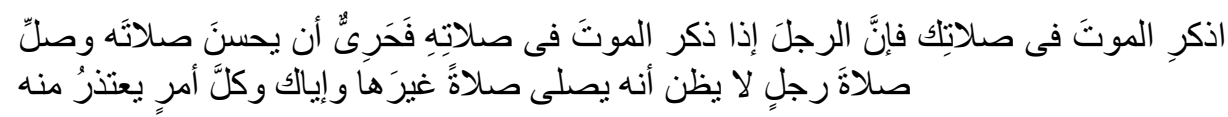

Ingatlah kematian dalam shalatmu karena jika seseorang mengingat mati dalam shalatnya, maka ia akan memperbagus shalatnya. Shalatlah seperti shalat orang yang tidak menyangka bahwa ia masih punya kesempatan melakukan shalat yang lainnya. Hati-hatilah dengan perkara yang kelak malah engkau meminta udzur (meralatnya) (karena tidak bisa memenuhinya)" (HR. Ad-Dailami dalam musnad Al-Firdaus, hadis ini hasan sebagaimana Seikh Al-Albani).

Dengan demikian, mengingat kematian akan menjadikan seseorang semakin mempersiapkan diri untuk berjumpa dengan Allah swt, karena barang siapa yang mempersiapkan diri untuk kematiannya maka ia akan berjumpa dengan Allah. Maka dari itu seseorang yang mempersiapkan bekal untuk kematiannya dialah orang yang mempersiapkan jawaban atas pertanyaanpertanyaan di hari hisab kelak atas segala perbuatan yang dilakukannya selama di 
dunia. Hal ini sebagaimana sabda nabi saw. sebagai berikut:

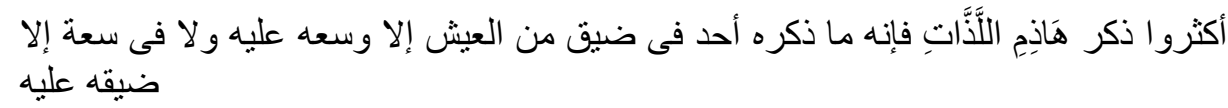

Perbanyaklah banyak mengingat pemutus kelezatan (yaitu kematian) karena jika seseorang mengingatnya saat kehidupannya sempit, maka ia akan merasa lapang dan jika seseorang mengingatnya saat kehiupannya lapang, maka ia tidak akan tertipu dengan dunia (sehingga lalai akan akhirat) (HR. Ibnu Hibban dan AL-Baihaqi, dinyatakan hadis ini hasan oleh syeikh Al-Albani).

Mengingat kematian juga akan menjadikan seseorang tidak berbuat dzolim di dunia. Hal ini sebagai man firman Allah swt:

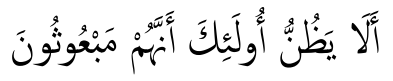

Tidaklah orang-orang itu menyangka, bahwa sesungguhnya mereka akan dibangkitkan (QS. Al-Muthofifin: 4).

Ayat ini dimaksudkan untuk orang-orang yang berbuat dzolim dengan cara curang dan menakar sesuatu dengan takaran yang tidak benar. Ayat ini juga menjelaskan bahwa apabila orang-orang yang berbuat dzolim itu mengetahui bahwa hari esok adalah hari kiamat tentu mereka tidak akan berbuat dzolim seperti itu lagi di dunia. Hal ini sejalan dengan pernyataan bapak Musthofa sebagaimana berikut:

Ari dakwah teh saur abi mah nya, penyampaian dibiji guru kanggo masyarakat tentang ilmu-ilmu sapertos fiqih,atanapi akblak, atanapi qur'an sareng sajabinalah merangkap kitu. Ari akidah nya tentang akblak, pami syariah mah nyaeta urusan nu sami berdekatan sareng akblak mung jalanna kana usaha atanapi urusan muamalah eta mah. Pami akblak mah panginten keseharian. Da pami ustad nu ngadugikeun ceramah oge aya nu kirang dipahami, tapi seuseurna mah dipahami sadayana, sareng dina keseharian oge naon nu ku ustad dingikeun sok dipraktekeun (hasil wawancara dengan Bapak Mustofa pada hari Minggu, 29 Juni 2018 pukul 09.15 WIB di rumahnya, beliau adalah salah satu warga masyarakat adat Kampung Dukuh yang berusia 42 tahun).

(Dakwah menurut saya adalah penyampaian dari seorang guru kepada masyarakat tentang ilmu-ilmu seperti fiqih, akhlak, atau qur'an dan yang lainnya. Kalau akidah yaitu pembahasan tentang akhlak, kalau syariah yakni urusan yang hampir berdekatan dengan akhlak hnya saja lebih kepada urusan muamalah, kalau untuk akhlak adalah urusan keseharian. Adapun ketika ustad memnberikan ceramah ada juga yang kurang dipahami, tetapi selebihnya jamaah memahami apa yang ustad sampaikan. Juga dalam keseharian apa yamg ustad sampaikan dapat kita praktekan dengan baik). Sejalan dengan pendapat ibu Rodjah sebagai berikut:

Dakwah saur ibu mah nya ustad nu sok ceramah di pangaosan. Alhamdulillah ari 
ceramahna sae mab sok sumanget ngadangukeunna ge, nu sok resep nagbodor. Ari pangaosan mah niatna ibadah weh ibu mah kangge tolab etang-etang nyiar elmu agama. Anu abirna mah sok tiasa naon nu ku ustad didugikeun teh tiasa didipraktekeun sadidinten (Hasil wawancara dengan Ibu Rojiah pada hari Minggu, 29 Juni 2018 pukul 11.30 WIB di rumahnya, beliau adalah salah satu jamaah Majelis Taklim Ibu-ibu Kampung adat Dukuh yang berusia 42).

(Dakwah menurut ibu yaitu ustad-ustad yang biasa ceramah di pengajian. Alhamdulillah jika ceramahnya menarik muncul semangat untuk mendengarkan terutama ustad yang suka melawak. Ikut pengajian sematamata niat untuk ibadah mencari ilmu dan pemahaman agama, yang pada akhirnya apa yang ustad zampaikan ini dapat dipraktekan dalam kehidupan sehari-hari).

Berdasarkan pernyataan dari para warga setempat dan jamaah Majlis taklim, dapat dinyatakan bahwa komunikasi dakwah yang dilakukan oleh para da'i di lingkungan kampong Dukuh sudah efektif dilakukan. Berdasarkan keefektifan dakwah yang dinyatakan oleh jamaah, ada enam indikasi keberhasilan dakwah yang telah dirasakan oleh warga kampung Dukuh, yaitu : 1) ceramahnya mudah dipahami karena disisipi dengan humor yang unik dan Tanya jawab, 2) pengajian sudah menjadi kebutuhan hidup yaitu warga merasa berdosa apabila tidak mengikuti pengajian, 3) warga masih percaya dengan pamali ceuk kolot baheula yang kemudian dikaitkan dengan nilai-nilai islami, 4) para Da’i memberikan contoh yang baik sebelum memberikan ceramah, 5) selalu ingat terhadap persiapan menghadapi kematian dengan amalan shalih, dan 6) selalu mempraktekan hasil ceramah yang disampaikan oleh Da’i.

\section{PENUTUP}

Hasil penelitian ini menunjukan bahwa da'i tidak bisa memaksakan materi yang berat karena mayoritas mata pencaharian penduduknya adalah petani; setiap da’i memahami bahwa dakwah wajib dilakukan setiap orang di kampung Dukuh dengan kemampuannya masing-masing; makna dakwah menurut para da'i di kampung Dukuh adalah 5T, yaitu Tujuan hirup(khaufullāh dan rahmatullāh), Tugas hirup (ibadah), Tata cara hrup (dengan taat kepada Allāh, rasul dan pemerintah), Tantangan hirup (harus kuat menghadapi cobaan), dan Tuntung hirup (selalu memperispkan diri untuk menghadapi kematian dengan ibadah). Dakwah di lingkungan kampung Adat Dukuh telah berjalan cukup efektif karena masyarakatnya secara umum memegang teguh prinsip 5T yang telah dijaga secara turun-temurun.

Berdasarkan hasil penelitian tersebut maka penelitian ini memberikan rekomendasi kepada prodi KPI program pascasarjana UIN Sunan Gunung Djati Bandung agar dapat mempublis karya illmiah ini di semua media publikasi yang 
Komunikasi Dakwah Pada Masyarakat Adat Kampung Dukuh Garut dimiliki agar dapat menjadi sumber rujukan untuk peneliti selanjutnya yang akan meneliti tentang dakwah di kampung adat. Kemudian untuk peneliti selanjutnya, penelitian ini hanya mengkaji unsur komunikasi dakwah di lingkungan kampung adat maka sangat disarankan kepada peneliti selanjutnya untuk memfokuskan penelitiannya pada aspek pengaruh dakwah yang dirasakan jamaah dari da'i-nya.

\section{DAFTAR PUSTAKA}

'Utsaimin, I. (1994) Syarh al 'Aqidah al Washithiyah, Cet. 2, Tahun 1415 H, Dar Ibnul Jauzi, 2/152 diakses 09 Januari 2019 dari https://almanhaj.or.id/ 3705-hisab-pada-hari-pembalasan.html

Al-Bayanuni, M. A. F. (2001). Al-Madkhal ila ilmi al-Da'wah, cet. III, Beirut: Resalah Publisher.

Aliyudin, M. (2016). Dakwah Kultural dalam Upacara Adat Ngalaksa dalam Ilmu Dakwah: Academic Journal for Homiletic Studies, 10(2), 271-289.

Al-Misry, A. (2005). Lisan al-'Arab li ibn Mandzur, jilid 15, cet IV, Beirut : Dar Sader Publisher.

Atabik, A. (2014). Konsep Komunikasi Dakwah Persuasif dalam Perspektif AlQur'an: At-Tabsyir Jurnal Komunikasi Penyiaran Islam, 2(2), 120-135.

Kahinah, D. L. (2014). Komunikasi Dakwah Dalam Masyarakat Multikultural di Kota Sorong, diakses 13 Maret 2018 dari http:/ / repositori.uin-alauddin.ac.id/

Mubasyaroh. (2017). Strategi Dakwah Persuasif dalam Mengubah Perilaku Masyarakat dalam Ilmu Dakwah: Academic Journal for Homiletic Studies, 11(2), 311-324.

Muharom, J. (2014) Peranan Tokoh Agama Kampung Naga dalam Penguatan NilaiNilai Keislaman pada Masyarakat Adat Kampung Naga. Diakses 02 Januari 2019 dari http://digilib.uinsgd.ac.id/5014/4/4_bab1.pdf 18 juli 2018Format Artikel jurnal

Muhtadi, A. S. (2012). Komunikasi Dakwah. Teori, Pendekatan, Aplikasi, Bandung: Simbiosa Rekatama Media.

Nasvian, M. F., dkk. (2013). Model Komunikasi Kyai dengan Santri (Studi Fenomenologi Pada Pondok Pesantren "Ribathi” Miftahul Ulum": Jurnal Wacana, 16(04), 2338-1884.

Nurdin. (2016).Pola Tabligh dalam Komunitas Adat Kampung Adat Dukuh Desa Ciroyom Kecamatan Cikelet Kabupaten Garut, (Bandung : http://digilib.uinsgd.ac.id/ 5042/ di akses pada 13 maret 2018).

Rahman, T. (2016). Komunikasi Dakwah Pesantren Tradisional. Ilmu Dakwah: Academic Journal for Homiletic Studies, 10(2), 375-397.

Safei, A. A. (2002). Dakwah Islam: Kajian Ontologis dalam Ilmu Dakwah: Academic Journal for Homiletic Studies, 1(1), 223-268.

Shihab, Q. (2007). Ensiklopedia AL-Quran Kajian Kosa Kata, Cet. I., Jakarta: 
Dede Sihabudin

Lentera Hati.

Suherdiana, D. (2009). Model Dakwah Fardiyah Tarekat Qodiriyah wa Naqsabandiyah dalam Ilmu Dakwah: Academic Joumal for Homiletic Studies, 4(14), 689-698. 